й подальша розробка на цій основі елементів методики дієвого формування полікультурної компетентності здобувачів освіти започаткує розвиток сукупності компетенцій, які міститимуть знання про культурну багатоманітність як цивілізації загалом, так і сучасного глобалізованого світу зокрема, що дозволятиме продуктивно виконувати професійні обов'язки вчителя нової української школи і педагога світового полікультурного освітнього простору.

Висновки. Дослідження системних зв'язків ідей В. О. Сухомлинського щодо значущості особистісно-соціального виховання 3 перспективними напрямами розвитку світової освіти переконливо засвідчують актуальність творчої спадщини видатного українського педагога. У цьому контексті формування й розвиток полікультурної компетентності здобувачів освіти створюватимуть інноваційні умови для ціннісного самовизначення суб'єктів освітнього процесу й узгодження цінностей вітчизняної педагогічної науки зі світовими трендами та цивілізаційними викликами.

Перспективи подальших наукових досліджень в означеному напрямі спрямовуватимуться на виявлення системних зв'язків перспективних надбань світової і вітчизняної педагогічної думки щодо ефективних методів навчання й особистісно-соціального виховання в умовах переходу від знаннєвої до компетентнісної освітньої парадигми.

\section{СПИСОК ВИКОРИСТАНОЇ ЛІТЕРАТУРИ}

1. Сухомлинський В. О. Сто порад учителеві / В. О. Сухомлинський // Вибрані твори : в 5 т. - Київ : Рад. шк., 1976. - Т. 2. - 670 с.

2. Оксфордський словник англійської мови [Електронний ресурc]. URL: https://www.oxfordlearnersdic tionaries.com/definition/english/competence (дата звернення: 05.07.2019).

3. Формирование профессиональной компетентности педагога. Поликультурная и информационная компетентность : учеб.пособие для вузов / Н. Р. Азизова, Н. А. Савотина, М. И. Бочаров, С. В. Зенкина. М. : Издательство «Юрайт», 2018. - 162 с.

4. Competences for democratic culture - Living together as equals in culturally diverse democratic societies [Електронний ресурc]. URL: https://rm.coe.int/ version-ukrainienne-240418/16807c886e (дата звернення: 05.07.2019).

5. MoPED. 3D Mapping of Ukrainian Education System [Електронний pecypc]. URL: http://moped. kubg.edu.ua/wp-content/uploads/2014/03/MoPED_ D1.2-3DMapping.pdf (дата звернення: 01.07.2019).

6. THE FUTURE OF EDUCATION AND SKILLS. Education 2030 [Електронний ресурс]. URL: https:// www.oecd.org/education/2030/E2030\%20Position \%20 Paper\%20(05.04.2018).pdf (дата звернення: 01.07.2019).

Дата надходження до редакиії: 10.07.2019 p.

Катерина МУЗИЧУК,

кандидатка технічних наук, доиентка кафедри інформаційно-комунікаиійних технологій та методики викладання інформатики

Рівненського державного гуманітарного університету

\title{
РОЗВИТОК КРИТИЧНОГО МИСЛЕННЯ ЗДОБУВАЧІВ ВИЩОЇ ОСВІТИ В УМОВАХ ЗМІШАНОГО НАВЧАННЯ
}

У статті розглянуто основні шляхи розвитку критичного мислення у здобувачів вищої освіти, в прочесі навчання яких використовуються сучасні інформаційні технологіï. Визначено принципи та характеристики навчання студентів за змішаною моделлю. На прикладі електронного навчального курсу, розробленого на платформі Moоdle, продемонстровано реалізачію відомих педагогічних технологій, які сприяють розвитку критичного мислення.

Ключові слова: критичне мислення, здобувач вищзої освіти, електронний навчальний курс, змішане навчання.

В статье рассмотрены основные пути развития критического мылиления у соискателей высшего образования, в прочессе обучения которых используются современные информационные технологии. Определены принциипы и характеристики обучения студентов по смешанной модели. На примере электронного учебного курса, разработанного на платформе Moоdle, продемонстрировано реализаияию известных педагогических технологий, которые способствуют развитию критического мышления.

Ключевые слова: критическое мышление, соискатель высшего образования, электронный учебный курс, смешанное обучение.

The article analyzes the issue of professional skills development for modern students during blended educational activities. In particular, the study deals with the critical thinking development, as the main indicator of the ability to self-analysis, self-study and self-improvement. 
Focusing on Ukrainian and foreign scientists' experience the notion, features and principles of blended learning organization, the basic technologies necessary for its providing have been defined. The classical approaches of the critical thinking development have been researched and it transferred to learning through the online environment. It has been singled out the electronic training course as a basic teaching and methodological support of the blended learning form. The notion of the electronic training course has been determined and its main components have been described.

The implementation of critical thinking development technologies has been demonstrated according to the example basing of the e-learning course «Modern Teaching Information Technologies》 developed on the Moodle platform. The author has emphasized the importance of the training sessions' organization under the conditions of blended learning form. The main stages of classes planning using the critical thinking theory have been characterized based on the T. Bandurovich's theory. These stages have been realized with the help of the Moodle platform means.

It has been given the examples of tasks that encourage students to think independently, work with information, put forward new ideas for solving issues and check their adequacy. The research stresses of individual and group project tasks, issue situational tasks. It has been recommended to use the training activities of the $« F o$ rum» and "Workshop» to organize such tasks in the e-learning environment. It gives the possibility to provide the interactive interaction in the form of asynchronous discussions. Besides mentioned training activities let students practice in questions formulation and network communication. The idea of HEI students' teaching according to the blended model has been characterized using the project task of web-quest development within the course "Modern Teaching Information Technologies».

It has been established that teaching students according to the blended form, using modern information technologies, can provide the critical thinking development. Among the modern lecturer tasks, it has been presented a skillful combination of interactive, information and communication technologies for the development of students who is able to make their own decisions connected with their professional orientation issues.

Key words: critical thinking, student, e-learning course, blended learning.

Постановка проблеми. Стан сучасної освіти характеризується низкою реформаторський ідей, які грунтуються на активному залученні в навчальний процес інформаційних технологій. Такі зміни відбуваються не лише в закладах середньої освіти, але й у закладах вищої освіти. Щоб реалізувати їх повною мірою, викладачі застосовують нові підходи та технології навчання. Це сприяє поступовій заміні традиційної освітньої діяльності на електронне навчання. Більшість закладів освіти сьогодні працюють за схемою змішаного навчання. Незважаючи на це, сучасному викладачеві потрібно пам'ятати про загальновідомі технології, що допомагають виховати майбутнього професіонала, який здатний до аналізу, самовдосконалення, критичної оцінки та знаходження рішень у проблемах професійного спрямування. Відкритим питанням на сьогодні лишається реалізація цих технологій за допомогою електронних навчальних курсів.
Аналіз наукових досліджень і публікацій. Поняття, принципи та закономірності функціонування критичного мислення вивчали як зарубіжні, так i вітчизняні науковці: В. Біблер, Т. Бізенков, П. Блонський, А. Брушлинський, М. Вертгеймер, Д. Вількеєв, Дж. Гілфорд, І. Ільясов, 3. Калмикова, І. Лернер, О. Лук, О. Матюшкін, М. Махмутов, С. Рубінштейн, Б. Теплов, О. Тихомиров, В. Шубинський та ін. Формуванню критичного мислення учнів у навчальній діяльності присвячені дослідження Ш. Амонашвілі, А. Байрамова, Т. Бізенкова, С. Векслера, Д. Джумалієвої, В. Казакова, В. Коневої, В. Крутецького, Г. Липкіної, Ф. Мінкіної, Л. Рибака, В. Синельнікова, С. Терно [7], О. Тихомирова та ін.

Частково вирішеною залишається проблема розвитку критичного мислення у здобувачів вищої освіти: визначено принципи та характерні особливості, проаналізовано фактори розвитку критичного мислення в закладах вищої освіти $[4 ; 6]$. У своїх працях $[8 ; 9]$ Т. Хачумян відзначає, що використання інформаційних технологій в освітній діяльності забезпечує розвиток критичного мислення. В основу іiі теорії покладено побудову інформаційно-педагогічного середовища, де переважають завдання пошукового, аналітичного характеру, висунення і перевірка гіпотез, створення спеціальних ситуацій знаходження та виправлення помилок. На прикладі студентів інженерно-педагогічних спеціальностей А. Аверишин та Т. Яковенко [1] довели, що комплексне застосування методів і форм інтерактивного навчання сприяє суттєвому підвищенню рівня сформованості критичного мислення у студентів.

Інформатизація освітньої діяльності спонукає до виникнення нових форм навчання, де поєднуються традиційне та електронне навчання - у науковій літературі більш відоме як змішана форма навчання. Теоретичними та практичними аспектами іiї впровадження в освітній процес займаються такі відомі науковці, як В. Кухаренко [6], О. Рафальська, Н. Рашевська, О. Спірін, Ю. Триус, Є. Смирнова-Трибульска та ін.

Проблема розвитку критичного мислення в умовах змішаного навчання на сьогодні вивчена не повністю.

Метою статті $є$ визначення способів та особливостей упровадження технологій розвитку критичного мислення у процес змішаної освітньої діяльності.

Виклад основного матеріалу. Освітня діяльність у закладах вищої освіти значною мірою залежить від сучасних тенденцій розвитку інформаційного суспільства. На зміну традиційним підходам виникають нові - нетрадиційні, в основу яких покладено активне використання сучасних інформаційних технологій. Прикладом такої організації освітньої діяльності $\epsilon$ змішане навчання. Цей підхід дозволяє одночасно поєднати традиційний спосіб викладання та часткове використання дистанційної форми навчання. Для традиційного навчання характерним $є$ те, що спілкування викладачів та студентів відбувається в аудиторії у строго визначений час, а серед носіїв даних перевага віддається традиційним друкованим виданням [10, с. 167]. У випадку дистанційного навчання комунікація викладача та студента відбувається позааудиторно через спеціальний освітній онлайн-ресурс та передбачає консультаційний характер, основними джерелами даних при цьому $є$ електронні ресурси, розроблені з використанням інформаційно-комунікаційних технологій. 
Сьогодні в більшості закладів вищої освіти України практикується часткове використання дистанційної форми навчання. Це насамперед пов'язано із особливостями життя сучасного суспільства і молоді, яка складає основний контингент серед здобувачів вищої освіти. Значна їх кількість, працюючи за фахом, набувають навичок практичної професійної діяльності під час навчання в університеті. Можливість бути повноцінним учасником освітньої діяльності позааудиторно дозволяє студентам поєднувати роботу та процес навчання. Організація освітньої діяльності за змішаною формою також приваблює здобувачів вищої освіти, які навчаються за індивідуальним навчальним планом, та студентів, що перебувають на вільному відвідуванні. Окрім цього змішане навчання характеризується особливостями, що визначають його переваги:

- гнучкість та доступність - розширює освітні можливості здобувачів вищої освіти завдяки можливості здобувати знання самостійно у слушний для себе час та зручному місці;

- індивідуалізація навчального процесу - під час розробки навчальних курсів змішаної форми враховуються індивідуальні можливості, потреби слухачів;

- підвищення ефективності освітнього процесу - змішане навчання виступає в ролі мотиватора для здобувачів вищої освіти, розвиває їхню самостійність, самоаналіз та критику мислення;

- зміна ролі викладача - за умов змішаного навчання викладач більшою мірою виконує функції консультанта та координатора маршруту навчання студента;

- персоналізація освітнього процесу - студент самостійно визначає свої навчальні цілі та способи їх досягнення, зважаючи на власні освітні потреби, інтереси і здібності;

- інформаційне наповнення курсів за допомогою інформаційно-комунікаційних технологій - навчальні курси в умовах змішаного навчання наповнені різноманітними матеріалами для візуалізації навчальної інформації: відео, відкриті освітні ресурси, інтерактивні дидактичні матеріали, інфографіка тощо [6, с. 52].

Основним навчально-методичним ресурсом, що забезпечує освітню діяльність здобувачів вищої освіти за змішаною моделлю $є$ електронний навчальний курс. Це комплекс електронних навчально-методичних матеріалів дисципліни, створених для організації індивідуального та групового навчання з використанням дистанційних технологій, що грунтуються на інтернет-технологіях відповідно до графіка навчального процесу закладу вищої освіти.

Електронний навчальний курс містить інструкційний, навчально-методичний та контролюючий блоки. Інструкиійний блок включає всі матеріали, необхідні для забезпечення та організації навчання за цим курсом, - анкети-опитувальники, інструкції щодо роботи в середовищі, загальну інформацію про курс та його цілі. Навчально-методичний - передбачає навчальні матеріали дисципліни до лекцій, практичних занять, лабораторних робіт, творчі завдання для виконання, перелік питань та джерел для самостійного опрацювання. Контролюючий блок містить завдання для проміжного та підсумкового контролю знань студентів.

У процесі розробки електронних навчальних курсів використовується спеціальне програмне забезпечення. Так, у Рівненському державному гуманітарному університеті на базі відкритої платформи дистанційного навчання Moodle створено навчальний інтернет-ресурс «Сервіс дистанційної освіти кафедри ІКТ та МВІ РДГУ»(http://do.iktmvi.rv.ua/), де розміщуються електронні навчальні курси, за якими навчаються здобувачі вищої освіти означеного ЗВО [3].

Сучасні випускники закладів вищої освіти - це всебічно розвинені особистості, які вміють знайти рішення у проблемних ситуаціях, зважаючи на власні знання, та здатні до саморозвитку. Формування таких якостей відбувається впродовж усього періоду навчання за допомогою сучасних технологій, методів, зокрема й технології розвитку критичного мислення.

Розглянемо шляхи розвитку критичного мислення в здобувачів вищої освіти на прикладі електронного навчального курсу «Сучасні інформаційні технології навчання», що розроблений для студентів, які навчаються на педагогічному факультеті Рівненського державного гуманітарного університету за спеціальністю 013 «Початкова освіта». Цей курс $\epsilon$ складовою циклу обов'язкових дисциплін для підготовки студентів означеної спеціальності та містить три змістових модулі: «Основні поняття інформаційних технологій. Шляхи використання в освіті», «Сучасні інформаційні технології як засіб візуалізації навчальної інформації», «Використання інформаційних технологій учителем початкової школи».

Метою курсу «Сучасні інформаційні технології навчання» $€$ формування теоретичних знань та практичних навичок роботи з комп'ютерною технікою, а також використання сучасних інформаційних технологій в освітньому процесі вчителя початкової школи.

Основними елементами будь-якого навчального курсу (звичайного чи електронного) є заняття, що мають визначену дидактичну структуру. Їх організація та наповнення моделюється викладачем самостійно таким чином, щоб у кінцевому підсумку сформувати у студентів необхідні знання та вміння і розвинути особливі якості, зокрема здатність до критичного мислення.

Т. Бандурович у занятті з використанням технологій критичного мислення виокремлює декілька фаз: виклик, осмислення, рефлексія. На етапі виклику формується проблема та визначаються цілі вивчення матеріалу. На етапі осмислення відбувається усвідомлення нового матеріалу та робота студента $з$ даними. Заключний етап передбачає осмислення студентом отриманого навчального матеріалу та формування в нього власного судження щодо досліджуваного матеріалу [2].

Зважаючи на можливості дистанційної системи Moodle, навчальні заняття електронного курсу, що розглядається, проектуються таким чином, щоб урахувати всі ці фази. Здобувачі вищої освіти до опрацювання навчальних матеріалів заняття ознайомлюються з його темою. Для подачі цього матеріалу використовується вбудований ресурс «Напис». Поруч із темою може бути наведений вислів відомої людини, який розкриватиме зміст заняття. Таким чином, студенти можуть самостійно передбачити цілі вивчення матеріалу.

Інформативне наповнення навчальних занять включає теоретичні відомості та практичні завдання. Воно представлене в електронних файлах, відеоматеріалах, інфографіці як гіперпосилання на інтернет-ресурси. У їх розміщенні в електронному курсі допомагають вбудовані в Moodle ресурси «Сторінка», «URL», «Файл». Під час проектування навчального заняття краще використовувати URL-адреси ресурсів, гіперпосилання, аніж цілком вбудовувати файли в курс. У такий спосіб викладач економить виокремлений мережевий простір. 
Наступним етапом роботи з навчальним заняттям $€$ вивчення нового матеріалу. Після цього відбувається його осмислення, виділення незрозумілих фактів та важливих моментів. Окрім того, здобувачі вищої освіти можуть самостійно вивчати додатковий матеріал із теми, враховуючи при цьому власні потреби. Осмислення нової інформації сприяє розвитку критичного мислення. На заключному етапі заняття ключовим запитанням до студентів $€$ «Для чого потрібний вивчений матеріал?». Знайти відповідь на нього студенти зможуть, виконавши завдання рефлексивної анкети. Такі анкети містяться наприкінці кожного заняття. Вони не оцінюються і використовуються з метою самоаналізу студентами своїх здобутків. Такі ресурси можуть бути подані у вигляді вбудованої Google Форми.

Уміння користуватися знаннями - важливий показник у розвитку критичного мислення. За результатами роботи викладач та студенти можуть зрозуміти, на скільки якісно засвоєно матеріал курсу і чи допоможе він їм знайти рішення в ситуаціях, які виникатимуть у майбутній професійній діяльності. Отже, електронні навчальні ресурси містять усі необхідні можливості, щоб забезпечити розвиток критичного мислення студентів у режимі онлайн.

«Із погляду навчального процесу критичне мислення слід розуміти як наукове мислення, головною метою якого є ухвалення незалежних, ретельно обміркованих і виважених рішень» [5, с. 121]. Автором теорії розвитку критичного мислення у процесі навчання $\epsilon$ український учений С. Терно. В основі означеної теоpiï - створення у процесі навчання проблемних ситуацій; використання кейсів; ознайомлення студентів із принципами, стратегіями та процедурами критичного мислення; створення ситуацій вибору; застосування інтерактивних форм навчання (діалогів, дискусій); передбачення письмового викладу розмірковувань студентів із подальшою рефлексією; надання студентам права на помилку та моделювання ситуації ії виправлення [7].

Під час проектування електронних навчальних занять важливо передбачати завдання, для вирішення яких студентам потрібно виявити вміння з пошуку даних, їх аналізу, структурування й адекватного подання, висунення і перевірки гіпотез, вироблення і зіставлення різних варіантів розв'язання завдання, аргументованого оптимального вибору [9]. Комплексну перевірку цих умінь викладач може здійснити за допомогою одноосібних та групових проектних завдань. Одним з етапів їх вирішення $€$ обговорення. Електронні освітні системи містять діяльності, що передбачають комунікативну взаємодію учасників навчального процесу. Ці ресурси забезпечують асинхронні дискусії, тобто такі, які відбуваються впродовж тривалого періоду. Зокрема, в системі дистанційного навчання Moodle вбудована навчальна діяльність «Форум». Вона має вигляд звичайного форуму, де кожен зі студентів може розмістити тему для обговорення та розпочати дискусію. Такий спосіб комунікації дозволить здобувачам вищої освіти пропонувати власні шляхи виходу із запропонованої проблемної ситуації, висловлювати свої сумніви $з$ приводу вибору стратегії чи, зважаючи на власний досвід, уносити рекомендації. Обговорення, яке передбачає аналіз, оцінку та систематизацію даних, - один із найпоширеніших методів стимулювання критичного мислення.

Для організації групових проектних завдань в електронних навчальних курсах варто скористатися діяльністю «Семінар». Ïї̈ основною особливістю $є$ можливість отримати не одну, а дві оцінки: за оцінювання робіт своїх одногрупників та за саму роботу.
Оцінюючи роботи інших, здобувачі вищої освіти займаються аналізом, формують власні судження, визначають переваги та недоліки в роботі й на основі цього формують висновки у вигляді оцінки.

Електронний навчальний курс «Сучасні інформаційні технології навчання» містить проблемні проектні завдання, а їх вирішення відбувається в окремо сформованих командах по п’ять учасників. Так, під час вивчення теми «Сучасні веб-технології навчання» студентам потрібно розробити веб-квест для учнів початкової школи. Вони самостійно обирають тему проекту, визначають цілі, яких потрібно досягти, розподіляють обов'язки між собою, здійснюють пошук даних із різних джерел, формулюють завдання веб-квесту, вибирають варіант представлення результату. Означене завдання передбачає дистанційний та очний етапи. Під час дистанційного відбувається процес виконання завдання, налаштування віддаленого спілкування між учасниками команд за допомогою використання можливостей середовища електронного курсу чи соціальних мереж. Очний етап передбачає поділ на команди, первинне обговорення проблеми, отримання консультацій від викладача курсу, захист проекту перед своїми одногрупниками та викладачем. Захист відбувається у формі семінару, де заслуховуються доповіді, під час яких студенти описують розроблені ними проекти та задають запитання своїм опонентам. Такий інтерактивний діалог допомагає студентам виробити вміння ставити запитання, що є важливим у їхній майбутній професійній діяльності.

Критичне мислення активізується за умов, коли нові, уже зрозумілі ідеї перевіряються, оцінюються, розвиваються та застосовуються. Їх перевірку на точність та адекватність можна здійснити навіть в умовах змішаного навчання, використовуючи сучасні інформаційні технології.

Висновки. Розвиток критичного мислення - одне 3 пріоритетних завдань сучасної освіти, оскільки людина з розвиненим критичним мисленням здатна самостійно засвоювати знання, перетворюючи цей процес на свідомий, безперервний та продуктивний. Це одночасно активний та інтерактивний процес. Можливості закладів вищої освіти у цьому випадку досить високі, а тенденція інформатизації освіти їх неабияк урізноманітнює. Основним завданням викладача сьогодні $€$ вміле поєднання інтерактивних, інформаційно-комунікаційних технологій із метою забезпечення розвитку критичного мислення у здобувачів вищої освіти.

Перспективи подальших наукових досліджень. У подальшому плануємо здійснити адаптацію технологій розвитку критичного мислення у процесі онлайн-вивчення інших предметів, а також удосконалити опанування дисципліни «Сучасні інформаційні технології навчання» 3 урахуванням технологій графічного моделювання даних.

\section{СПИСОК ВИКОРИСТАНОЇ ЛІТРРТУРИ}

1. Авершин А. О. Формування критичного мислення у студентів інженерно-педагогічних ВН3 [Електронний ресурс] / А. О. Авершин, Т. В. Яковенко // Проблеми інженерно-педагогічної освіти : збірник наук. пр. - Х. : УІПА, 2009. - Вип. 24-25. C. 238-246. - URL: http://repo.uipa.edu.ua/jspui/handle/ 123456789/793 (дата звернення: 22.05.2019). 
2. Бандурович Т. М. Використання технології критичного мислення як засобу створення творчого мікроклімату на уроці світової літератури [Електронний ресурс] / Т. М. Бандурович // Освітній інтернет-навігатор : науково-методичний інтернет-журнал. URL: http://oin. in.ua/vykorystannya-tehnolohiji-krytychnoho-myslennyayak-zasobu-stvorennya-tvorchoho-mikroklimatu-naurotsi-svitovoji-literatury/ (дата звернення: 22.05.2019).

3. Павлова Н. С. Практика використання елементів дистанційного навчання у підготовці вчителів інформатики / Н. С. Павлова, К. П. Музичук // Фізико-математична освіта. - 2018. - Вип. 1(15). C. 269-275.

4. Романова С. Розвиток критичного мислення особистості як проблема сучасної освіти [Електронний ресурс] / С. Романова, О. Денисевич // Вісник національного авіаційного університету. - 2009. - № 2. C. 113-118. - (Серія «Педагогіка, психологія»). URL: http://jrnl.nau.edu.ua/index.php/VisnikPP/article/ view/2124/2115 (дата звернення: 22.05.2019).

5. Скорик Ю. М. Критичне мислення педагога як освітня технологія / Ю. М. Скорик // Вісник Черкаського університету. - 2016. - Вип. 2. - С. 120-124. (Серія «Педагогічні науки»).
6. Теорія та практика змішаного навчання : монографія / В. М. Кухаренко, С. М. Березенська, К. Л. Бугайчук, Н. Ю. Олійник [та ін.] ; за ред. В. М. Кухаренка. - Харків : Міськдрук, НТУ «ХПІ», 2016. - 284 с.

7. Терно С. О. Теорія розвитку критичного мислення (на прикладі навчання історії) : посібник для вчителя / С. О. Терно. - Запоріжжя : Запорізький національний університет, 2011. - 105 с.

8. Хачумян Т. I. Поняття «критичне мислення» та його сутність у психолого-педагогічній науці / T. I. Хачумян // Теоретичні питання культури, освіти та виховання : зб. наук. пр. - К. : ВЦ КНЛУ, 2003. Вип. 24. - Ч. 2. - С. 171-177.

9. Хачумян Т. І. Формування критичного мислення студентів вищих навчальних закладів засобами інформаційних технологій : дис. ... канд. пед. наук : 13.00.09 / Хачумян Тетяна Іванівна ; Харківський національний педагогічний ун-т ім. Г. Сковороди. - Х., 2005. - 221 с.

10. Шроль Т. С. Змішане навчання як нова форма організації ІКТ-освіти / Т. С. Шроль // Оновлення змісту, форм та методів навчання і виховання в закладах освіти. - 2016. - Вип. 13 (56). - Ч. 1. - С. 166-170.

Дата надходження до редакиіï: 12.06.2019 р.

Лариса ПАНІНА,

кандидатка історичних наук,

доиентка кафедри суспільно-гуманітарної освіти

Рівненського ОІППО

\section{ВИКОРИСТАННЯ} ІНФОРМАЦІЙНО-КОМУНІКАЦИЙНИХ ТЕХНОЛОГІЙ У ПРОЦЕСІ РЕАЛІЗАЦІї МОВНО-ЛІТЕРАТУРНОЇ ОСВІТИ

У статті охарактеризовано інформаційно-комунікаційні технології та їх використання у навчальному проиесі. Наведено приклади електронних освітніх ресурсів, щзо сприяють підвищенню мотивації та якості навчання учнів у процесі реалізації мовно-літературної освіти.

Ключові слова: інформаційно-комунікаційні технології, комп ютерні комунікації, інформаційні технологї̈ навчання.

В статье охарактеризованы информационно-коммуникационные технологии и их использование в учебном прочессе. Приведены примеры электронных образовательных ресурсов, способствуюших повышению мотивачии и качества обучения учащихся в процессе реализачии культурно-литературного образования.

Ключевые слова: информационно-коммуникаиионные технологии, компьютерные коммуникации, информационнье технологии обучения.
In the article the possibilities of using information and communication technologies are outlined.The electronic learning resources that contribute to increasing the motivation and quality of students' learning in the Ukrainian language and literature lessons are described.

The rapid development of the means of information (computers, computer communications, any electronic devices) gave impetus to modern technologies for processing, transmission, reception and storage of information. Information and communication technologies are components of increasing the motivation to study, which should be taken into account when forming the modern educational process. These technologies contribute to the widespread use of analytical, practical, experimental learning principles, aimed at schoolchildren. Despite the considerable number of studies and publications devoted to certain aspects of the informatization of the process of professional training, the conceptual apparatus of modern educational information and communication technologies needs to be clarified. 